\title{
Ethno-didactic Specifics of Training Chinese Students in the Russian Language: The Experience of Russian Universities
}

\author{
Iliya F. Isaev, Tatyana V. Samosenkova”, Fyodor I. Sobyanin, Irina B. Ignatova, Tatyana F. Novikova \\ Belgorod State University, Russia
}

Received July 22, 2019; Revised September 20, 2019; Accepted September 30, 2019

Copyright $\bigcirc 2019$ by authors, all rights reserved. Authors agree that this article remains permanently open access under the terms of the Creative Commons Attribution License 4.0 International License

\begin{abstract}
The paper systematizes and generalizes the ethno-oriented experience of teaching Russian as a foreign language in the education systems of Russia and China. The number of foreign subjects wishing to study for a degree in Russia is now increasing; it is almost the same as it was before the perestroika times. The majority of foreign students come from China. In order to make the training effective, ethnic and cultural specifics should be taken into consideration in teaching Russian as a foreign language. The extent of previous research in the field is insufficient, which accounts for relevance of this study. The research findings described in the paper may be used to develop new training methods and to adjust the current ones.
\end{abstract}

Keywords Ethno-didactics, World Vision, National Educational Environment, Education System, Educational Stereotype, Training Methods

\section{Introduction}

Native language is a cognitive tool, that is, it serves as a means of environment perception and assessment. It also enables us to accumulate social and individual experience. However, numerous scholars (T.M Balykhina, 2011; V.V. Vorobyov, 1996; Yu.E. Prokhorov, 2003; Nisawa, Y. (2018) and others insist that in the first place, language reflects the way a specific ethnic and cultural community perceives the world. It creates an ideo-ethnic world view. Researchers provide two interpretations of the "world view" notion. First, it is an aggregate of objective knowledge about reality (the so-called conceptual world view), its components include vital notions and concepts. Second, it is a world view reflected by specific signs containing information on objective reality (the so-called linguistic world view). Axiological world image plays a significant role in the linguistic world view, as it contains a people's system of values. Axiological world image implies a secondary division of reality, which is subjective, as the assessment depends on an individual's physical and mental nature, his/her existence and senses. It predetermines a person's mentality and activity, as well as his/her attitude towards other people and objects. According to K.D. Ushinsky (1998) there are some general consistent patterns in the development of mankind as a whole, while the education system of each nation displays identity, the latter being the main idea of the nations' existence. Such identity dictates national specifics of any education system, education technologies and pedagogical principles applied by states. Therefore, the fact that each nation has a unique education system must not be ignored, as the efficiency of the training process is highly dependent on it.

\section{Results and Discussion}

Many years of teaching Chinese students reveal that their national (Students from Dalian University of foreign languages, Dezhou University, Qingdao University (China University of petroleum) and others study in BelSU), cultural and educational traditions often disagree with Russian education technologies.

Our experience shows that these students find it difficult to adapt to other educational strategies and prefer to act according to the rules which they are used to. Their behavior is stereotypic as they have become accustomed to their national educational environment. E. Passov (1989) stresses that «apart from linguistic aspect, mutual understanding is made up of sociological, socio-cultural, axiological and psychological aspects».

In training Chinese students, Russian universities should take into account both positive and negative personal factors. The former includes determination, industriousness and good memory, while the latter may be 
associated with the difference in Russian and Chinese educational technologies and some personal reasons, such as lack of linguistic capacity, poor linguistic training received in China, lack of personal motivation, poor health condition and so on.

There is no doubt that China is among the traditional (postfigurative) cultures. The ideology of Confucianism dominating in China is a doctrine of morals and ethics. Judging by its background, it is an enlightened form of ancestor cult, which is the main characteristic of a postfigurative culture. Basic Confucianist categories include rite, commitment, philanthropy, and a noble man is perceived to be an ideal human. Confucianist ideal of life is «obey the voice of your heart and do not break the rules». The essence of this philosophy is to correlate a person's rights and responsibilities with traditions displayed in numerous rites and rituals. They serve as examples of reasonable behavior.

The education system of China, which is also based on Confucius' 2500-year-old theory of human development and self-perfection, differs significantly from the European system, including the Russian one. The Chinese system aims at bringing up «an ideal man», which also implies educational requirements. As knowledge of the complicated hieroglyphic system was necessary for obtaining information from ancient texts, conventional linguo-didactics at that time was based on reading and writing. Owing to the strong adherence to national traditions, these two activities remain a priority in Chinese pedagogy and common language teaching technologies. It means less attention is paid to communicative aspects of language study. This is the first characteristic feature of language education in China.

The second one is connected with the way theoretical material is presented. Theoretical information pertaining to language system is presented as ready-made patterns and algorithms, which contributes to forming certain educational stereotypes in language learning.

We understand educational stereotype as a steady monotony of students' academic activities. Educational stereotype which takes place in language learning results in a cognitive activity stereotype. The latter, in its turn, forms stereotypes in linguistic and verbal thinking.

The above specifics of China's language teaching tradition exert influence on the social and cultural determination. Being closely connected with typological personality characteristics, stereotypic mentality depends on the social and cultural determination. Stereotypes induce people to act automatically. Once a person develops stereotyped reactions, he/she has no more freedom of choice, as these stereotypes are sustainable and tend to control habitual actions. If a stereotype is broken, a person feels depressed and stressed, and in some cases even displays aggression.

Hence, the stereotypic character of such language teaching methods, far from building flexible verbal skills, does not allow for any ability to vary syntactic structures and grammar categories. It becomes an obstacle for Chinese students trying to learn Russian, which is a rather complicated language system with various stress patterns, flexible word order, co-existence of various grammatical forms and other characteristics which do not always fall into line.

As noted, before, typological personality characteristics of respective nations need to be taken into consideration when teaching foreign students. These include nation-specific psychological characteristics which are basic to educational technologies. The famous scholar in linguistic psychology and ethnical studies, A.A. Potebnya (2007) paid attention to this issue in his research. In studying ethno-psychical specifics of cognitive and mental skill building mechanisms, he was based on the following aspects:

a) apart from being a nations' distinguishing feature, language contributes to the formation of respective ethnos;

b) the nation-specific psychological identity of an ethnos consists in thinking techniques reflected in the respective language;

c) the uniqueness of a language spoken by the nation results in national mentality specifics;

d) education and culture serve as means of consolidating and enhancing the ethno-psychical identity.

For the purposes of this research, we will interpret the nation-specific psychological features to be the components of national psychology which characterize the distinctiveness of mental processes and psychical conditions, as well as the specifics of interaction, relations and communication between representatives of a particular ethnos. The structure of Chinese ethnotype nation-specific features includes the following components:

- motivation and background reflected in industriousness, efficiency, determination, diligence and persistence. These features are based on philosophical and religious postulates of Confucianism and represent traditional national values fixed in the Chinese public mind;

- mental and cognitive components which reflect the specifics of cognition and thinking and allow for a manifestation of these specifics via a unique combination of cognitive and mental features including: a) a low cognitive (operational) potential, which manifests itself by avoidance of complicated logical operations (analysis, abstraction, reasoning). However, this drawback is repaired by a compensatory potential (intuition, instinctive understanding of contexts and situations); b) mnemonic abilities (having some memory reserve); c) reliance on visual and motor memory rather than audial memory (which accounts for relative inattentiveness and even neglect of exercises aimed at listening skills and note-taking); 
- emotional and volitional components which influence the performance and manifest themselves in emotional specifics: on the one hand, Chinese students are emotional, on the other, they are introverted and reserved, sometimes even impenetrable.

Thus, the didactic specifics, instructional technologies and students' cognitive activity are determined by the civilizational experience accumulated by the ethnical groups the students belong to. Therefore, they are variable depending on the nation. That is why the above specifics need to be taken into consideration when dealing with students who represent distant cultures (which include ethnic groups of China), irrespective of the education stage and form of training.

It appears reasonable to analyze education traditions in terms of cultural paradigm and activity-based approach. They may also be narrowed down to a particular aspect, for example, to language training specifics.

We can recommend some preferential methods and techniques enabling us to adapt training to the needs of Chinese students:

1. Demonstration method with a reading and writing support proves to be most effective.

2. Translation and interpretation of meaning are especially effective in the semantization of linguistic material.

3. Explanation method is applied, along with instruction-giving or with comparing the facts of the foreign language with their counterparts in the students' native language, or, less often, with those in an intermediary language, for example, English. Deductive method relying on axioms is the main way to introduce new material.

4. Drilling method implies practicing linguistic facts in substitution, analogy and pattern exercises.

5. The controlled practice stage mainly includes speech exercises containing question-and-answer tasks and dialogues.

6. Creative tasks require special attention, as students need to be prepared and pre-instructed in order to perform them.

7. Demonstration method (visual support) is essential at any stage of training.

8. Mistake correction and tests must be thorough, systematic and reference-based.

China's didactics is primarily based on teaching the system of a foreign language, that is, it is grammar-oriented. Sufficient attention is paid to the lexical aspect. Learning by heart is also among the strategies applied. In introducing linguistic material, as well as in reading, preferable methods include visual support combined with motoric activity (the writing type). Where possible, the students' native language should be used.

Another specific feature should be noted, and that is the students' age. Exchange students $\left(2^{\text {nd }}\right.$ and $3^{\mathrm{d}}$ years of study $)$ or those studying under « $2+2 »$ Programme are adults. It means the teacher's primary task is to «reveal the essence of training at each stage with a view to promoting professional (linguistic, verbal, pedagogical) development of the linguistic personality in future specialists. In doing so, the teacher should:

1) appeal to the students' educational and linguistic experience and their independence;

2) push the envelope and build inner grounds in foreign students enabling them to control their studying efficiently (including knowledge, skills, abilities, methods of study and so on) » (Samosenkova, 2012; Sailaukyzy, A. 2018; Shaker Mehdi Rahimi, M., \& Zare, M. (2016).

Those who study the Russian language in China have to memorize large information volumes and must be able to reproduce them. This, however, does not include any text analysis, interpretation and expressing the students' personal attitude. The training system applied does not allow for any creative skills to be formed, such as probability prediction. Thus, students who have experience of language training in China are inclined to non-communicative styles of foreign language learning. They find it difficult to build verbal skills, and it takes them a long time to overcome the psychological barrier in communication.

Students may also face challenges in building writing skills. Beyond doubt, writing used to be the main development tool for the Chinese civilization. Still, the graphic aspect of the Chinese language is unique, the hieroglyphic images are motivated by objects and phenomena, while Cyrillic writing is based on a different graphic and orthographic system, which is why Chinese students find it difficult to reproduce texts in Russian.

We have found that the following methods and techniques prove efficient in building written speech competences in Chinese students (Ignatova, Petrova, Samosenkova, 2003) (methods and techniques which are not used in China's conventional didactics are marked with the asterisk $(*)$ :

1. Introduction - perception (audio perception with or without a visual support), pronouncing (reading aimed at memorizing the audial/visual image), somatization (guessing, translation), writing.

2. Finding meaning - analysis* (letter-sound, word-building, textual, semantic analysis), synthesis (systematization), comparison (detecting distinguishing features), combining*, generalizing*, specification, prediction.

3. Drill - listening, pattern actions: imitation, transformation, substitution, construction, answering questions using a support.

4. Controlled practice method - questions and answers, describing, retelling, argumentation*, analyzing fellow-student's utterances*, summarizing*. 
5. Self-correction - analyzing* and editing the student's own written utterance (notes, printed text, lecture, summary, abstract, text plan).

6. Self-control - self-assessment, written reproduction of a full text of a lecture or part thereof written with contractions*, oral message/report on a specific topic using speechnotes or layouts as a support.

The ability to use written sources in a foreign language provides a rapid increase of awareness in professional spheres. Along with traditional genres or written speech (such as note-taking, summarizing, abstract writing, talking points preparation), people increasingly use new types of written communication, such as Internet conferences (online conferences). These trends are possible due to the spread of influence and boost in the use of contemporary information sources, including the Internet. In order to achieve the goal, a person must be able to plan his/her utterances, to distribute information and present it piece by piece, which implies the use of logical operations including analyzing, drawing analogies, comparing, contrasting, suggesting, proving etc. A specific orientation of a written utterance provides a unity of the goal, content and form, it determines the genre and type of the work performed and the choice of linguistic means, as well as the extent of fullness (that is, a detailing of a lecture written with contractions) or ultimate brevity (notes of a printed text, summary or abstract).

Experimental use of the above methods in teaching Chinese students to write in Russian, taking into consideration their specific features, have enabled us to build the following skills in these students:

1) building utterances in a way which allows to fill in any possible gaps that may lead to misunderstanding,

2) expanding utterances in order to achieve a fuller presentation of information or to contract it avoiding excessiveness and stressing the most significant points,

3) arranging utterances to render information clearly and distinctly.

We believe there are some pre-requisites for Chinese students pursuing educational goals at Russian universities. They include the following:

1. Chinese students have a significant memory potential which is necessary for cognition.

2. Chinese hieroglyphic writing is based on visual images.

3. Chinese ethnotype is oriented toward absorbing a maximum information volume.

4. Chinese students possess a big volitional potential. They are determined, proactive, independent, prone to self-analysis and self-control.

As a rule, Chinese students are proactive in class, and they are socially oriented. Owing to the specifics of the Chinese ethnotype, they also prefer teamwork, and team performance is more significant for them than individual results.

\section{Conclusions}

Building a unified multi-cultural and educational space is a global civilization-wide objective. It can be achieved by means of a multilateral cross-cultural dialogue contributing to people's mental compatibility and intellectual exchange.

In order to implement educational goals when dealing with Chinese students (Lexical minimum of Russian as a foreign language, 2011), the specifics of national education systems should be taken into consideration, along with China's traditions in linguo-didactics. Chinese students face a different socio-cultural environment in Russia. At the same time, Russian educational standards are being modified to meet Bologna process requirements, providing for European educational systems to be unified. Given these facts, additional training tactics should be used, with new techniques introduced gradually and persistently. It will enable Chinese students to become acquainted with the European education system. The use of «soft» linguo-didactic technologies will help avoid unreasonable steps in training and may allow us to appeal to ethical and moral principle shared by the Chinese: "The one who argues, either in the beginning, or later on, is in delusion, in a stream of victories and losses». We believe the recommendations proposed will allow for an effective academic adaptation of Chinese students at Russian universities.

\section{REFERENCES}

[1] Arutjunova, N. D. (1988). Typy jazykovyh znachenij: Ocenka. Sobytie. Fakt [Types of linguistic meanings: assessment. Event. Fact]. Moscow: Nauka. 341 p. (in Russian)

[2] Balyhina, T. M., \& Jujczjan, C. H. (2011). Ot metodiki k jetnometodike. Obuchenie kitajcev russkomu jazyku: problemy i puti ih preodolenija [From methods to ethnic methods.training Chinese students in the Russian language: challenges and solutions]: monograph. Moscow: RUDN. (in Russian)

[3] Bobrysheva, I. E. (2001). Uchjot nacionalnyh lingvometodicheskih tradicij v obuchenii russkomu jazyku inostrancev (na primere Kitaja) [Consideration of national traditions of linguodidactics in teaching Russian to foreign students]. Moscow: "Sputnik" Company. (In Russian)

[4] Burov, V. G. (2000). Kitaj i kitajcy glazami rossijskogo uchenogo [China and the Chinese as perceived by a Russian scholar]. Moscow. [Electronic resource]. URL: http://www.philosophy.ru (in Russian)

[5] Ignatova, I. B., Petrova, L. G., \& Samosenkova, T. V. (2003). Obuchenie russkomu jazyku inostrannyh 
studentov-rusistov v rusle koncepta "jazykovaja lichnost"' [Teaching Russian to foreign students of Russian studies in terms of the "linguistic personality" concept]. Monograph. Belgorod State University publishing house. (in Russian).

[6] Nisawa, Y. (2018). Applying van Hiele's Levels to Basic Research on the Difficulty Factors behind Understanding Functions. International Electronic Journal of Mathematics Education, 13(2), 61-65. https://doi.org/10.12973/iejme/26 96

[7] Lexical minimum of Russian as a foreign language. (2011). The first certification level. The General knowledge. M. Moscow State University; St. Petersburg: Zlatoust, 2011.

[8] Passov, E. I. (1989). Osnovy kommunikativnoj metodiki obuchenija inojazychnomu obshheniju [Basics of communicative methods in training to communicate in a foreign language]. Moscow. (in Russian).

[9] Potebnya, A. A. (2007). Jazyk i narodnost [Language and national spirit]. [Electronic resource]. URL: genhis.philol. msu.ru/article_158.shtml (In Russian).

[10] Prokhorov, Yu. E. (2003). National socio-cultural stereotypes of speech communication and their role in teaching Russian to foreigners. M.: Editorial, URSS.

[11] Samosenkova, T. V. (2012). Otrazhenie russkoj i kitajskoj jazykovoj kartiny mira: nacionalno-kulturnaja specifika [Reflection of the Russian and Chinese linguistic word image: the national and cultural specifics]. Monograph. Belgorod: Politerra (in Russian).

[12] Sailaukyzy, A., Shakuova, R., Sak, K., \& Lebedeva, T. (2018). Contemporary view to the history of Kazakhstan's democratic journalism and publicism. Opción, 34(85-2), 774-799.

[13] Shaker Mehdi Rahimi, M., \& Zare, M. (2016). The effectiveness of therapy based on acceptance and commitment social anxiety and general self-efficacy on divorced women under welfare organization in Yazd. UCT Journal of Social Sciences and Humanities Research, 4(4), $10-16$

[14] Ushinsky, K. D., (1998). O narodnosti v obshhestvennom vospitanii. Antologija gumannoj pedagogiki. Ushinsky [On ethnicity in public education. Antology of humane pedagogics. Ushinsky]. Moscow (in Russian).

[15] Vorobiev, V. V. (1996). Linguocultural paradigm of the personality. M. 